\title{
The Effect of Knowledge, Attitude and Practice (KAP) Covid-19 on the Work Stress of Nurses in Emergency Installations of the General Hospital Center Dr. Wahidin Sudirohusodo
}

\author{
Hasri Khumaerah Abrar ${ }^{1}$, Irwandy ${ }^{1}$, Atjo Wahyu ${ }^{2}$ \\ ${ }^{1}$ Department of Hospital Management, Faculty of Public Health, Hasanuddin University, \\ Indonesia \\ ${ }^{2}$ Department of Occupational Health and Safety, Faculty of Public Health, Hasanuddin \\ University, Indonesia
}

\begin{abstract}
Disease transmission among health workers is associated with overcrowding, absence of isolation facilities, and environmental contamination. Knowledge of disease will influence the attitude and practice of medical staff. Wrong attitudes and practices directly increase the risk of infection. This study aims to analyze the influence of Knowledge, Attitude, Practice (KAP) nurses who handle the COVID-19 pandemic in the Emergency Room of the General Hospital Center (RSUP) Dr. Wahidin Sudirohusodo. This research is a quantitative research. The design used was analytic observational with a cross-sectional study approach. A sample of 83 nurses was selected using purposive sampling technique with the criteria of nurses on duty in the hospital. Data were analyzed using the Logistic Regression test. The results of multivariate analysis obtained p-value below 0.05 ( $\mathrm{p}<0.05)$, meaning that the attitude and practice variables had an influence on the dependent variable (job stress). For the most dominant variable that affects work stress, it can be seen from the largest OR value, namely practice with $\mathrm{OR}=4.484$. The high $\mathrm{OR}$ value obtained means that practice is the most dominant variable affecting the dependent variable, namely work stress. The hospital management identifies the behavior of each employee in an effort to adjust their needs, provides training programs to maintain and protect themselves while working, and the incentives obtained. So that employees can work calmly and be confident in their work. It is suggested for further research to be able to use other research designs, so that we can find out factors other than KAP that can affect work stress, either directly or indirectly.
\end{abstract}

Keywords: Knowledge, Attitude, Practice, Work Stress, Covid-19

Received: October 30, 2020

Revised: November 14, 2020

Accepted: November 21, 2020

\section{Introduction}

Coronavirus disease 2019 (referred to as "COVID-19") is a respiratory disease caused by the new coronavirus. This disease was first discovered in Wuhan, China in December 2019. This disease is highly contagious with its main clinical symptoms including fever, dry cough, fatigue, myalgia, and dyspnea. In China, 18.5\% of COVID-19 patients progress to a severe stage, which is characterized by acute respiratory distress syndrome, septic shock, refractory metabolic acidosis, bleeding and coagulation (WHO, 2020a).

According to WHO, the Coronavirus disease (COVID-19) outbreak in 2019 has become a pandemic. At the time of writing, the disease has affected more than 100,000 people and caused more than 3,000 deaths worldwide. As of February 2020, the virus has infected 3,019 health workers and caused 5 deaths (WHO, 2020b). Based on data obtained from the Makassar City Health Office (2020) regarding Covid-19, the number of positive cases continues to increase, 
namely 656 positive consisting of 319 treated, 289 recovered and 48 others died. The number of cases of people under monitoring (ODP) is 1,013 people consisting of 312 still under monitoring and 701 people who have finished monitoring. The number of patients under surveillance is 861 people consisting of 231 people who are still under surveillance, 543 who were declared noncovid-19 and 87 others died.

The increase in the number of patients in the hospital resulted in an increasing demand for health services. The increasingly high demands for work professionalism have brought great pressure to be faced by individuals in the corporate work environment. An increase in job demand that is not balanced with available job resources will result in work pressure (Schaufeli et al., 2009; Bakker \& Demerouti, 2014; Cheng et al., 2020). Apart from pressure from the work environment, the work goals desired by the company can also generate pressure. Stress that arises and continues to cause anxiety is known as distress. Distress is the result of a response to stress that is unhealthy, negative, and destructive (destructive). When a person experiences distress, that person will tend to overreact, be confused, and cannot perform optimally (Walker.J, 2002).

Medical workers who are at the forefront of fighting the Covid-19 corona virus are certainly more susceptible to infection. The fact that health workers are at risk of contracting the epidemic chain is an important issue because health workers help control the epidemic. This condition certainly makes them depressed in the middle of their humanitarian work. So far, quite a number of doctors and nurses around the world have been infected with the Covid-19 corona virus from their patients. General Hospital Center (RSUP) Dr. Wahidin Sudirohusodo, there were 16 medical personnel infected after treating Covid-19 patients even though they had used complete or incomplete personal protective equipment (PPE). One of the causes is work fatigue and work stress with increasing job demand. As many as $30 \%$ of hospital staff experienced work pressure in the form of back pain, $28 \%$ complained about stress, $20 \%$ felt tired, and $13 \%$ experienced headaches.

Therefore, actions that can be taken in an effort to control the spread of infection, especially for medical staff as the front line, are by identifying risk factors for infection. This is done to determine the right action to take in reducing the risk of being infected with the virus (WHO, 2020c). Knowledge (knowledge) about the disease will affect the attitude (attitude) and practice (practice) of medical staff, and wrong attitudes and practices will directly increase the risk of infection (McEachan et al., 2016). Understanding the knowledge, attitudes and practices of health workers (KAP) and possible risk factors can help predict the outcome of planned behavior.

In the study, it was found that common sources of work stress were due to inadequate and inappropriate knowledge and abilities in the hospital 14. Ashkani-Esfahani et al (2016) revealed that officers who have greater practical experience have lower levels of job stress. The existence of a positive attitude towards safety issues can significantly reduce work stress (Dickety et al., 2005; Kiani et al., 2012), such as preparedness in the face of an outbreak. The KAP research in Iran found that work stress with a prevalence level of $22.5 \%$ was greatly influenced by a higher level of knowledge $(\mathrm{OR}=0.82)$, than the level of attitude $(\mathrm{OR}=0.71)$, and the level of practice $(\mathrm{OR}=0.78)$, and employees who participate in training programs have the lowest level of work stress (OR = 0.51) (Alavi et al., 2016). The influence of knowledge, attitude, and practice on work stress is considered to have a significant relationship with radiation staff employees.

Based on the health problem, namely the current Covid-19 pandemic, researchers were then interested in combining previous research on Knowledge, Attitude, Practice (KAP) with the work stress of nurses who handled the COVID-19 pandemic, especially nurses who were at RSUP Dr. Wahidin Sudirohusodo. The hospital is a Class A Hospital which is also a referral hospital chosen by the Government as a reference in handling Covid-19 patients in South Sulawesi. So this study 
aims to see the effect of each knowledge, attitude, practice (KAP) on the work stress of nurses in the emergency department (IGD) of RSUP Dr. Wahidin Sudirohusodo.

\section{Methods}

This type of research is a quantitative study using an observational study with a Cross Sectional Study approach. This research was conducted at the Emergency Department (IGD) of RSUP Dr. Wahidin Sudirohusodo Makassar City. The population of this study were all nurses who performed services and served in the Emergency Room of RSUP Dr. Wahidin Sudirohusodo. The sample size in this study using total sampling is all nurses who provide services and work in the Emergency Room of RSUP Dr. Wahidin Sudirohusodo, namely 83 people. The instrument used in data collection was a questionnaire, regarding the independent variables in the form of occupational safety and health, while the dependent variable was the variable organizational commitment. The questionnaire used in this study was first tested for validity and reliability. Based on the results of validity and reliability tests using the SPSS program with 62 statement items in the questionnaire, all statements are declared valid and reliable.

Univariate analysis was conducted to describe the characteristics of the respondents, descriptive analysis of the research variables and to analyze the cross tabulation between the characteristics of the respondents and the research variables. The bivariate analysis was carried out to determine the relationship between each independent variable and the dependent variable using the Chisquare test. The multivariate analysis was carried out to see the level of influence of the independent variables on the dependent variable using the Logistic Regression test.

\section{Results and Discussion}

Table 1. Frequency Distribution Based on Characteristics of Respondents at the Emergency Room at RSUP Dr. Wahidin Sudirohusodo in 2020

\begin{tabular}{|c|c|c|c|}
\hline \multicolumn{2}{|c|}{$\begin{array}{c}\text { characteristics } \\
(n=83)\end{array}$} & $\begin{array}{c}\text { Frequency } \\
\text { (n) }\end{array}$ & $\begin{array}{c}\text { Percentage } \\
(\%)\end{array}$ \\
\hline \multirow[t]{4}{*}{ Age } & 17-25 Years & 1 & 1.2 \\
\hline & 26-35 Years & 39 & 47.0 \\
\hline & $36-45$ Years & 35 & 42.2 \\
\hline & 46-55 Years & 8 & 9.6 \\
\hline \multirow[t]{4}{*}{ Last Education } & Diploma II & 21 & 25.3 \\
\hline & S.KEP & 9 & 10.8 \\
\hline & NERS & 50 & 60.2 \\
\hline & Others & 3 & 3.6 \\
\hline \multirow[t]{2}{*}{ Sex } & Male & 17 & 20.5 \\
\hline & Female & 66 & 79.5 \\
\hline \multirow[t]{2}{*}{ Employee Status } & Civil Servant & 49 & 59.5 \\
\hline & Others & 34 & 41.0 \\
\hline \multirow{2}{*}{$\begin{array}{l}\text { While serving in } \\
\text { the ER, you have } \\
\text { treated Covid-19 } \\
\text { patients }\end{array}$} & Yes & 76 & 91.6 \\
\hline & No & 7 & 8.4 \\
\hline
\end{tabular}

Source: Primary data, 2020

Table 1 shows the frequency distribution based on the characteristics of the sample at the study location. Based on the results of the frequency distribution analysis, it can be seen that 
most respondents are in Dr. Wahidin Sudirohusodo is found in the largest age group, namely respondents in the age range 26-35 years as many as 39 people (47\%). Most of the respondents' last education was NERS as many as 50 people $(60.2 \%)$. In the gender category, it was found that most of the respondents were women as many as 66 people $(79.5 \%)$. For the type of work category, most of the respondents were as civil servants as many as 49 people (59\%) with experience of having served in the emergency room caring for Covid-19 patients as many as 76 respondents $(91.6 \%)$.

Table 2. The Relationship between Knowledge, Attitudes, and Practices with Work Stress in the Emergency Room at RSUP Dr. Wahidin Sudirohusodo2020 year

\begin{tabular}{|c|c|c|c|c|c|c|c|}
\hline \multirow{3}{*}{$\begin{array}{l}\text { Research } \\
\text { Variable }\end{array}$} & \multicolumn{4}{|c|}{ Work Stress } & \multirow{2}{*}{\multicolumn{2}{|c|}{ Total }} & \multirow{3}{*}{$p$-value } \\
\hline & \multicolumn{2}{|c|}{ High } & \multicolumn{2}{|c|}{ Low } & & & \\
\hline & $\mathbf{n}$ & $\%$ & $\mathbf{n}$ & $\%$ & n & $\%$ & \\
\hline \multicolumn{8}{|l|}{ Knowledge } \\
\hline High & 129 & 77,7 & 37 & 22,3 & 38 & 100,0 & \multirow{2}{*}{0.041} \\
\hline Low & 3 & 4,7 & 61 & 95,3 & 45 & 100,0 & \\
\hline \multicolumn{8}{|l|}{ Attitude } \\
\hline High & 31 & 91.2 & 3 & 8.2 & 34 & 100,0 & \multirow{2}{*}{$\mathbf{0 , 0 0 9}$} \\
\hline Low & 32 & 65.3 & 17 & 34.7 & 49 & 100,0 & \\
\hline \multicolumn{8}{|l|}{ Practice } \\
\hline High & 41 & 89.1 & 5 & 10.9 & 46 & 100,0 & \multirow{2}{*}{0,002} \\
\hline Low & 22 & 59.5 & 15 & 40.5 & 37 & 100,0 & \\
\hline
\end{tabular}

Source: Primary data, 2020

Table 2 describes the relationship between the independent variable and the dependent variable. Based on the results of the analysis found in the first variable, of the 38 respondents had a high level of knowledge with a high level of work stress as many as 33 respondents $(86.8 \%)$. The obtained value of $p=0.041(p<\alpha=0.000<0.05)$, which means that there is a significant effect between knowledge on work stress in the emergency room at Dr. Wahidin Sudirohusodo. The second variable, found that the attitude level is high with a high work stress level as many as 31 respondents $(91.2 \%)$. The obtained value of $p=0.009(\mathrm{p}<\alpha=$ $0.000<0.05)$, which means that there is a significant influence between attitudes towards work stress in the emergency room at Dr. Wahidin Sudirohusodo. The third variable, found that the level of practice is high with a high level of work stress as many as 41 respondents (89.1\%). The obtained value of $p=0.002(p<\alpha=0.000<0.05)$, which means that there is a significant effect between practice and work stress in the emergency room at Dr. Wahidin Sudirohusodo.

Table 3. The Influence of Knowledge, Attitudes, and Practices with Work Stress in the Emergency Room at RSUP Dr. Wahidin Sudirohusodo 2020 year

\begin{tabular}{|c|c|c|}
\hline Independent Variable* $^{*}$ & P value & OR (95\% Cl) \\
\hline Knowledge & 0.237 & $2.093(0.616 \pm 7.116)$ \\
\hline Attitude & 0.040 & $4.195(1.066 \pm 16.511)$ \\
\hline Practice & 0.012 & $4.484(1.388 \pm 14.486)$ \\
\hline
\end{tabular}

*Dependent variable: Job Stress

Source: Primary data, 2020

Table 3 shows the effect of the independent variable and the dependent variable. Based on the results of the analysis, it can be seen that the $\mathrm{p}$ value is below $0.05(\mathrm{p}<0.05)$, which means 
that the variable knowledge $(\mathrm{p}=0.237)$, attitude $(\mathrm{p}=0.040)$, and practice $(\mathrm{p}=0.012)$ have an influence on the dependent variable (Job Stress). For the variable that has the most dominant influence on Work Stress, it can be seen from the largest OR value, namely Practice with OR $=4.484$. Because the greatest OR value, the practice variable is the most dominant variable affecting the dependent variable, namely Job Stress.

The proportion of respondents' answers regarding the knowledge variable consists of 7 questions with a score range of 1 (one) to 5 (five). Distribution of respondents' answers to each statement for knowledge variables in the emergency department at Dr. Wahidin Sudirohusodo most of the respondents answered that they mastered statements regarding the variable of knowledge, but there were still answers that did not understand some of the statements on the correct use of disinfectants by $3.6 \%$ and the technique of removing and disposing of disposable masks by $2.4 \%$. Based on the research results obtained the frequency distribution for the knowledge variable from 83 respondents at the emergency room at Dr. Wahidin Sudirohusodo, as many as 38 respondents (45.8\%) with good knowledge and 45 respondents $(54.2 \%)$ with bad knowledge.

The results of this study are supported by a theory in which knowledge or cognitive is a very important domain for the formation of an action. Behavior based on knowledge will be more lasting than those not based on knowledge (Notoatmodjo, 2010). According to Mubarak et al (2007), the higher a person's education, the easier it is for them to receive information and the more knowledge they have. Knowledge is not only obtained in education but can also be obtained from information either directly or indirectly.

The results of the analysis of the influence of knowledge on work stress showed that of the 38 respondents with good knowledge and high work stress, 33 respondents (86.8\%) and 5 respondents $(13.2 \%)$ had low work stress. Meanwhile, of 45 respondents with poor knowledge and high work stress, 30 respondents $(66.7 \%)$ and 15 respondents $(33.3 \%)$ had low work stress. So more less knowledge on nursing actions, nursing records and evaluations. This can be caused by a lack of information / reading nursing books because they are already busy with work and other matters. It could also be due to the lack of coaching in the nursing field or the supervision of the head of the nursing room.

The factors that affect a person's knowledge are as follows: Education means the guidance that a person gives to others about something so that they can understand. It cannot be denied that the more educated a person is, the easier it is for them to receive information, and in the end the more knowledge they will have. Conversely, if someone has a low level of education, it will hinder the development of one's attitude towards the acceptance of information and new values are introduced. The Provincial General Hospital has a minimum nursing education of Diploma III of Nursing. Respondents of this study have the title S.Kep.Ners. So the more educated nurses are, the easier it will be for nurses to receive information, and in the end the more knowledge they will have.

Distribution of respondents' answers to each statement for attitude variables in the emergency department at Dr. Wahidin Sudirohusodo most of the respondents answered sometimes to statements about attitude variables, but there were still rare answers to several statements such as patient honesty if he had traveled or had direct contact with a patient infected with the Covid-19 virus as many as 25 respondents (30.1\%). Based on the results of the study, the frequency distribution for attitude variables from 83 respondents at the emergency room at Dr. Wahidin Sudirohusodo Hospital, 34 respondents (41\%) with good attitudes and 49 respondents $(59 \%)$ with bad attitudes. 
Attitude is a state of self that moves humans to act or perform both social activities with certain feelings in response to objects (situations or conditions) in the surrounding environment. In addition, attitude also provides readiness to respond positively or negatively to objects or situations. Attitude is a tendency to respond (positively or negatively) to certain situations or objects. Attitudes are not carried from birth, but are learned and shaped based on experience and practice throughout individual development. Azwar (2008) said the formation of attitudes is influenced by several factors, namely personal experience, culture, other people who are considered important, mass media, educational institutions or institutions and religious institutions, and emotional factors in individuals.

The result of statistical test showed that the value of $p=0.009$, because the value of $p<\alpha=$ $0.000<0.05$ then Ho was rejected, this means that there is a statistically significant effect on work stress in the emergency room at Central General Hospital (RSUP) Dr. Wahidin Sudirohusodo. This is in line with research conducted by Noor et al (2016) which states that what are the conditions of job stress and job satisfaction on employee performance / attitudes, where there is a unidirectional relationship between Job Stress and Job Satisfaction on Employee Performance / attitudes, and affect partially or simultaneously on employee performance / attitude. Meanwhile, the independent variable that most influences employee performance / attitude is job stress.

Various situations and working conditions can be a potential source of stress because every aspect of the work environment can be perceived as stress by workers. Nurses' perspective in seeing work situations will determine the amount of stress experienced by nurses. Job stress shows that the causes or sources of work stress are internal and external factors, internal factors consisting of education, motivation, knowledge, interpersonal relationships, attitudes and behavior, creativity and health conditions at work. Meanwhile, external factors are the work environment, income level, social management guarantees, labor efficiency, achievement opportunities and technology.

And there is a relationship between the level of work stress of nurses on the caring behavior of nurses, namely according to (Perry \& Potter, 2004), stated that nurses who are unable to relieve stress will have an impact on decreasing work performance and deteriorating service to patients. In health care, nurses who experience severe stress will experience burnout and lose motivation to work. The high stress experienced by nurses at work makes nurses bored and bored, ultimately affecting work productivity and decreasing nurse performance (Weimann \& Weimann, 2017).

Distribution of respondents' answers to each statement for practice variables in the emergency department at RSUP Dr. Wahidin Sudirohusodo, most of the respondents answered rarely to statements regarding practice variables such as the statement of implementing "My 5 Moment Hand Hygiene" from WHO as many as 27 respondents $(32.5 \%)$. Based on the research results obtained the frequency distribution for practice variables from 83 respondents at the emergency department at RSUP Dr. Wahidin Sudirohusodo, as many as 46 respondents $(55.4 \%)$ with good practices and 37 respondents (44.6\%) with bad practices.

The statistical test results obtained $p$ value $=0.002$, because the value of $p<\alpha=0.000<0.05$ then Ho is rejected, this means that there is a statistically significant effect of practice on work stress in the emergency room at RSUP Dr. Wahidin Sudirohusodo. This is in line with the research conducted by Suminarsis \& Sudaryanto (2017), The results of examining the relationship between student stress levels and coping mechanisms obtained from the cross tabulation between the two showed that the heavier the stress level of students, the UMS 
students who were carrying out field learning practices at the hospital had a functional coping mechanism.

Practices or behaviors are human actions or activities that have a very wide range. Behavior is all human activities or activities, either directly observed or not observed from outside parties. Each individual has his own behavior that is different from other individuals. However, at a minimum, if it is based on sufficient knowledge, positive behavior will be formed relatively long (Notoatmodjo, 2010). The source of stress most felt in the second rank was based on research by Khateer (2014), namely stress with peers and daily life. Where the nursing students of the Jordan University in the first and second year of clinical practice feel that there is competition with peers both on campus and in the clinical practice environment, they feel pressured by the evaluations carried out by the teacher because they compare with other students, are unable to get along with peer groups during practice clinics, and feel that clinical practice has an impact on their outside activities.

Distribution of respondents' answers to each statement for work stress variables in the emergency room at Dr. Wahidin Sudirohusodo, the dominant respondent, answered never. In the statement regarding work stress with the largest percentage, namely $79.5 \%$ (66 respondents) in statement no.22 "During the current Covid-19 pandemic, I was injured when I took medical action on a patient (such as being pricked by a needle, broken by an ampoule, etc.) ". Based on the research results obtained the frequency distribution for work stress variables from 83 respondents at the emergency room at Dr. Wahidin Sudirohusodo, as many as 63 respondents $(75.9 \%)$ with high work stress and 20 respondents $(24.1 \%)$ with low work stress.

The results of the logistic regression test together with the variables of knowledge, attitudes, and practices on work stress in the Emergency Room at Dr. Wahidin Sudirohusodo obtained the results that based on the variables in the equation the value of Constant $(\mathrm{Bo})=-6.370$, the logistic regression coefficient value for the independent variable knowledge $(B 1)=0.739$, attitude $(\mathrm{B} 2)=1.320$, and practice $(\mathrm{B} 3)=1.377$. The $\mathrm{p}$ value of each independent variable is knowledge $=0.237$, attitude $=0.062$, and practice $=0.024$. Taking into account the p value, only the practice variable has a $\mathrm{p}$ value $<0.05$. This means that only practice variables have an influence on job stress. The same thing was produced by Salsabila (2015), The results of the stress level measurement show that $100 \%$ of respondents from the class of 2012 and $91.7 \%$ of the class of 2013 are at a moderate level of stress, and $8.3 \%$ of respondents from the class of 2013 are at a high stress level.

In carrying out their duties and profession, nurses are vulnerable to stress. Every day, in carrying out her service, a nurse does not only relate to the patient, but also with the patient's family, patient friends, fellow nurses, with doctors and regulations in the workplace as well as workloads that are sometimes judged to be inappropriate for physical conditions psychic and emotional. Work stress in the scope of nursing work will have different levels, depending on the stressors in the work unit and the responses to these stressors. When looking at several studies, it is known that the level of work stressors in the emergency department is higher than in other work units (Sexton et al., 2000).

\section{Conclusion}

Based on research on the Influence of Knowledge, Attitude, and Practice (KAP) on Work Stress in the Emergency Room at Dr. Wahidin Sudirohusodo In 2020, researchers formulated the conclusion that there is a statistically significant influence on work stress, there is a statistically significant influence on attitude (Attitude) on work stress, and there is a statistically significant influence on practice (Practice) on stress. work. It is expected that the 
hospital management can pay attention to the stressful experiences of nurses while working in the hospital. The need for an effective health education and training program aimed at increasing knowledge of Covid-19.

\section{References}

Alavi, S. S., Dabbagh, S. T., Abbasi, M., \& Mehrdad, R. (2016). Radiation protection knowledge, attitude and practice (RP-KAP) as predictors of job stress among radiation workers in Tehran Province, Iran. Iranian Red Crescent Medical Journal, 18(10).

Azwar, S. (2008). Sikap dan Perilaku Dalam: Sikap Manusia Teori dan Pengukurannya. Yogyakarta: Pustaka Pelajar.

Bakker, A., \& Demerouti, E. (2014). Chen, P., Cooper, C., eds. Chichester, United Kingdom: Wiley-Blackwell, 3, 37-64.

Cheng, H., Yang, H., Ding, Y., \& Wang, B. (2020). Nurses' mental health and patient safety: An extension of the Job Demands-Resources model. Journal of Nursing Management, 28(3), 653-663.

Dickety, N., Weyman, A., \& Marlow, P. (2005). Measuring workplace transport safety performance health and safety laboratory. Researchportal Bath.

Mubarak, W. I., Chayatin, N., \& Rozikin, S. (2007). Promosi kesehatan sebuah pengantar proses belajar mengajar dalam pendidikan. Yogyakarta: Graha Ilmu, 30..

Kiani, F., Samavtyan, H., Poorabdiyan, S., \& Jafari, E. (2012). How safety trainings decrease perceived job stress: the effects of improvement in employees attitude toward safety issues. Far east journal of psychology and business, 6(4), 46-58.

McEachan, R., Taylor, N., Harrison, R., Lawton, R., Gardner, P., \& Conner, M. (2016). Meta-analysis of the reasoned action approach (RAA) to understanding health behaviors. Annals of Behavioral Medicine, 50(4), 592-612.

Noor, N. N., Rahardjo, K., \& Ruhana, I. (2016). Pengaruh Stres Kerja Dan Kepuasan Kerja Terhadap Kinerja Karyawan (Studi Pada Karyawan Pt Jasaraharja (Persero) Cabangjawatimur Di Surabaya). Jurnal Administrasi Bisnis, 31(1), 9-15.

Notoatmodjo. (2010). Ilmu perilaku kesehatan. Jakarta: Rineka Cipta.

Perry \& Potter. (2004). Fundamentals of Nursing: Concepts, Process, and Practice. 4th edn. Missouri: Mosby- Year Book Inc.

Salsabila, I. (2015) Program studi ilmu keperawatan fakultas kedokteran dan ilmu kesehatan universitas islam negeri syarif hidayatullah jakarta $1434 \mathrm{~h} / 2013 \mathrm{~m}$. UIN Syarif Hidayatullah Jakarta.

Schaufeli, W. B., Bakker, A. B., van der Heijden, F. M., \& Prins, J. T. (2009). Workaholism among medical residents: It is the combination of working excessively and compulsively that counts. International Journal of Stress Management, 16(4), 249.

Sexton, J. B., Thomas, E. J., \& Helmreich, R. L. (2000). Error, stress and teamworking in aviation and medicine. BMJ, 320, 745-749.

Suminarsis, T., \& Sudaryanto, A. (2017). Hubungan antara tingkat stres dengan mekanisme koping pada mahasiswa keperawatan menghadapi praktek belajar lapangan di rumah sakit. Jurnal Berita Ilmu Keperawatan, 2(3). 
Ashkani-Esfahani, S., Bagheri, F., Emami, Y., Esmaeilzadeh, E., Azarpira, N., Hassanabadi, N., .. \& Noorafshan, A. (2016). Protective effects of co-enzyme Q10 on thioacetamide-induced acute liver damage and its correlation with behavioral, biochemical, and pathological factors. Iranian Red Crescent Medical Journal, 18(8).

Weimann, E., \& Weimann, P. (2017) High Performance in Hospital Management, High Performance in Hospital Management. Berlin, Germany: Springer Berlin Heidelberg. doi: 10.1007/978-3-662-49660-2.

WHO. (2020a). 2019-nCoV outbreak is an emergency of international concern. World Health Organization. Available at: http://www.euro.who.int/en/healthtopics/emergencies/pages/news/new s/2020/01/2019-ncov-outbreak-is-anemergency-of-international-concern.

WHO. (2020b). Coronavirus disease (COVID-2019) situation reports. World Health Organization. Available at: https://www.who.int/emergencies/diseases/novelcoronavirus-2019/situation-reports.

WHO. (2020c). Guidance for health workers. World Health Organization. Available at: https://www.who.int/emergencies/diseases/novel-coronavirus-2019/technical guidance/health-workers. 